\title{
Burdens, Presumptions and Confusion in the Law on Want of Knowledge and Approval
}

\section{Brian Sloan*}

\section{Introduction}

Against a background of alleged increases to will challenges in England and Wales, ${ }^{1}$ the possible impact of incoherence and uncertainty in the law (as well as their inherent undesirability) and the Law Commission's recent Consultation Paper on wills, ${ }^{2}$ this article critically considers the doctrine that a testator must know and approve of the contents of a valid will. The essence of the doctrine is that the will ${ }^{3}$ must "truly represent the testator's testamentary intentions", ${ }^{4}$ according with the "natural and popular idea of the nature of a will". 5 That said, there is doubt as to the extent to which it is necessary that the testator understands the true impact of the will's provisions, ${ }^{6}$ a problem that the Law Commission hopes to solve. ${ }^{7}$

Amid claims that the law of "want of knowledge and approval" is not always what litigants should plead when they do, ${ }^{8}$ the article critically explores three ostensibly fundamental principles related to it, particularly in light of the difficult and contradictory Court of Appeal decision in Gill $v$

\footnotetext{
* Fellow in Law, Robinson College, Cambridge. An earlier version of this article was presented at the $8^{\text {th }}$ Annual Meeting of the Association for Law, Property and Society. I am grateful (subject to the usual disclaimer) for comments from participants and Siôn Hudson.

${ }^{1}$ See, e.g., L. Warwick-Ching, "Wills face legal challenges as house prices surge" Financial Times, 7 April 2017 at https://www.ft.com/content/2f03763e-1a0c-11e7-bcac-6d03d067f81f [Accessed 29 October 2017]. Cf. J. Bryant, "Trusts and estates cases: can statistics help to identify trends? - spotlight on probate and estates cases" (2016) 22 Trusts and Trustees 962.

${ }^{2}$ Law Commission, Making A Will (Law Commission Consultation Paper 231, 2017) (“C.P. 231”).

${ }^{3}$ Cf. Re Singellos [2010] EWHC 2353 (Ch) at [164] (Deputy Judge Andrew Simmonds QC).

${ }^{4}$ Fuller v Strum [2001] EWCA Civ 1879, at [59] (Chadwick LJ), approved in Marley v Rawlings [2014] UKSC 2; [2015] A.C. 129.

${ }^{5}$ Hastilow v Stobie (1865) 1 P. \& D. 64, at 67 (Sir J.P. Wilde).

${ }^{6}$ Compare, e.g., Brown v Deacy [2002] W.T.L.R. 781 at [15] (Kim Lewison QC) with Hoff v Atherton [2004] EWCA Civ 1554. See, e.g., P. Reed, "Capacity and Want of Knowledge and Approval” in B. Häcker and C. Mitchell (eds.), Current Issues in Succession Law (Oxford: Hart Publishing, 2016), p.182.

${ }^{7}$ C.P. 231, Consultation Question 40. See, e.g., Gill v Woodall [2010] EWCA Civ 1430 (Lloyd LJ).

${ }^{8}$ R. Kerridge, “Wills Made in Suspicious Circumstances: The Problem of the Vulnerable Testator” [2000] C.L.J. 310.
} 
Woodall. ${ }^{9}$ One of the key difficulties with the law on want of knowledge and approval is that, as it was understatedly put, the identification of the burden of proof is "a little complicated, as it often is in probate cases, where presumptions can play a part". ${ }^{10}$ The main principles addressed by this article (Principles 1, 2 and 3 respectively, albeit not so described in the case law) are therefore: (1) that the propounder of a will must "prove" it; (2) that a testator with capacity who duly executes a will is nevertheless presumed to know and approve of its contents, shifting the evidential burden from the will's propounder to its challenger; and (3) that (notwithstanding Principle 2) "suspicious circumstances" will require affirmative proof of knowledge and approval. In Gill, Lord Neuberger arguably both invoked and doubted Principle 2, as well as questioning the traditional approach to Principle 3. The article investigates the origin, ${ }^{11}$ normative justifications and current status of the principles, and particularly whether they are compatible with each other. It argues that in several respects the law is undesirably inconsistent and unclear, making it potentially too easy to challenge a will and at the very least risking excess litigation, and makes several proposals for reform. It also considers the Law Commission's reform proposals, which largely hope to "repair" knowledge and approval indirectly by changing the related doctrine of testamentary undue influence, arguing that they may not provide a comprehensive solution.

\section{Principle 1: The Propounder of a Will Must "Prove" That Will}

The basic principle that the propounder ${ }^{12}$ must establish knowledge and approval appears to be one of the least controversial contentions in the relevant case law. This may suggest that the real controversy comes from the other principles and Principle 1's interaction with them. The burden in relation to knowledge and approval ${ }^{13}$ is part of a broader principle that the propounder must prove the will, which also relates to compliance with the formality requirements in the Wills Act $1837 .{ }^{14}$ It will be seen, however, that these matters are all the subject of presumptions broadly analogous to

\footnotetext{
${ }^{9}$ [2010] EWCA Civ 1430.

${ }^{10}$ Re Morgan [2008] W.T.L.R. 73 at [35] (Mark Herbert QC). See further R. Kerridge, "Draftsmen and Suspicious Wills" in M. Dixon (ed.), Modern Studies in Property Law - Volume 5 (Oxford: Hart Publishing, 2009), p.161.

${ }^{11}$ See, generally, Kerridge, "Draftsmen and Suspicious Wills".

${ }^{12}$ I.e. "the party who puts forward a document as the will of a testator": Cleare v Cleare (1869) 1 P. \& D. 655 , at 657 (Lord Penzance).

${ }^{13}$ A plea apparently first allowed only in Hastilow v Stobie (1865) 1 P. \& D. 64 (Kerridge, "Draftsmen and Suspicious Wills", p.162).

${ }^{14}$ Wills Act 1837, s. 9, concerning writing, signature and minimally two witnesses.
} 
Principle 2, and in Cleare v Cleare Lord Penzance held that the burden can be discharged "through the medium of a presumption unrebutted, or of positive evidence to that end". ${ }^{15}$

In the 1838 case of Barry v Butlin, Parke B was clear that "the onus probandi lies in every case upon the party propounding a Will; and he must satisfy the conscience of the Court that the instrument so propounded is the last Will of a free and capable Testator". ${ }^{16} \mathrm{He}$ simply stated that the rule was "undisputed", ${ }^{17}$ and that " $[\mathrm{t}]$ he strict meaning of the term onus probandi is...that if no evidence is given by the party on whom the burthen is cast, the issue must be found against him". ${ }^{18}$ The consequence of this, which he spelt out in Baker v Batt, is that "if the conscience of the Judge, upon a careful and accurate consideration of all the evidence on both sides, is not judicially satisfied, that the paper in question does contain the last Will and Testament of the deceased, it is bound to pronounce its opinion that the instrument is not entitled to probate". ${ }^{19}$ Strictly, if sufficient proof is not forthcoming, the will fails, and this can happen "without the imputation of wilful perjury on either side". ${ }^{20}$ The burden is a legal ${ }^{21}$ ("or persuasive") ${ }^{22}$ one requiring proof on the balance of probabilities. ${ }^{23}$

While it is arguable that Principle 1 merely reflects the law's general approach to a civil claim, in some cases the person(s) challenging the will can be described as the claimant(s) because the litigation concerns the revocation of probate already granted. ${ }^{24}$ It might also be thought that requiring a burden to be satisfied in the case of every will is inconsistent with an understandable desire to avoid unnecessary litigation. ${ }^{25}$ Nevertheless, in Inchbald v Inchbald, Deputy Judge John Martin QC suggested that in practice the burden is cast upon the propounder only "[o]nce an

\footnotetext{
15 (1869) 1 P. \& D. 655, at 657.
}

16 (1838) 2 Moo. P.C. 480, at 482, described as "binding on courts of first instance and...at least highly persuasive for the Court of Appeal" (Perrins v Holland [2010] EWCA Civ 840 at [28] (Sir Andrew Morritt C)).

17 (1838) 2 Moo. P.C. 480, at 483.

18 (1838) 2 Moo. P.C. 480, at 484. See further Hart v Dabbs [2001] W.T.L.R. 527 at [72].

19 (1838) 2 Moo. P.C. 317 , at 320.

${ }^{20}$ Ibid. For discussion of remedies in instances of mistake, see, e.g., B. Sloan, Borkowski's Law of Succession 3rd edn. (Oxford: OUP, 2017), pp. 94ff.

${ }^{21}$ See, e.g., Cushway v Harris [2012] EWHC 2273 (Ch) at [3] (Henderson J).

22 J. Ross Martyn et al, Theobald on Wills, 18th edn. (London: Sweet \& Maxwell, 2016) at [3-020].

${ }^{23}$ See, e.g., Re Butcher [2015] EWHC 1240 (Ch) at [9] (Deputy Judge Lesley Anderson QC).

${ }^{24}$ See, e.g., Re Reynolds [2005] EWHC 6 (Ch).

${ }^{25}$ Particularly since "[a]s far as non-contentious probate is concerned, the formalities for execution of a valid English Will do not include any kind of independent verification of knowledge and approval" (B. Rich, "What does "want of knowledge and approval' mean in the 21st century?" [2008] P.C.B. 303, p.303). See, e.g., Kerridge, "Wills Made in Suspicious Circumstances", pp.332-3. 
allegation of want of knowledge and approval is made". ${ }^{26}$ Moreover, the Civil Procedure Rules requires a party contending that a testator did not know or approve of a will's contents to give particulars of the facts and matters relied on. ${ }^{27}$

It has already been mentioned that presumptions have traditionally played a pivotal role in this area, and it seems unlikely that the basic notion in Principle 1 can realistically be removed from English succession law. While the Law Commission has provisionally proposed a statutory presumption of capacity, it may wish to give further thought to how that would interact with Principle $1 .^{28}$ The focus of this article is therefore inevitably on other principles in the law of want of knowledge and approval, and the extent to which they support, and render practical Principle 1.

\section{Principle 2: A Testator with Capacity who Duly Executes a Will is Presumed to Know and Approve of its Contents}

\section{Formulations and Rationale of the Principle}

In Barry v Butlin, Parke B was content to say that the burden imposed by Principle 1 "is in general discharged by proof of capacity, and the fact of execution, from which the knowledge of and assent to the contents of the instrument are assumed". ${ }^{29}$ This Principle 2 is potentially significant even if it is "only an evidential presumption which may be displaced where the circumstances in which the will was made give rise to a sufficient suspicion that the contrary may be true" ${ }^{30}$ such suspicions traditionally relating to Principle 3 (considered in the next section).

The rationale of Principle 2 is clear enough: it prevents the practical difficulties, of laboriously proving the will in every case, that would otherwise arise if Principle 1 were to exist in undiluted form. In Gill v Woodall, Lord Neuberger was anxious that "a court should be very cautious about accepting a contention that a will...is open to challenge", ${ }^{31}$ even if "its terms are surprising, inconsistent with what [a testatrix] said during her lifetime, unfair, or even vindictive or

\footnotetext{
${ }^{26}$ [2016] EWHC $3215(\mathrm{Ch})$ at [7].

${ }^{27}$ Civil Procedure Rules 1998/3132, r. 57.7(3).

${ }^{28}$ C.P. 231, Consultation Question 6.

${ }^{29}$ (1838) 2 Moo. P.C. 480, at 484. See also Cleare v Cleare (1869) 1 P. \& D. 655, at 657-8 (Lord Penzance).

${ }^{30}$ Minns v Foster 2002 WL 31914915 at [119] (Deputy Judge Michael Briggs QC).

${ }^{31}$ Gill v Woodall [2010] EWCA Civ 1430 at [16].
} 
perverse". ${ }^{32}$ Since "[w]ills frequently give rise to feelings of disappointment or worse on the part of... would-be beneficiaries", ${ }^{33}$ he was concerned that:

\begin{abstract}
"Human nature [means that] such people will often be able to find evidence, or to persuade themselves that evidence exists...that the will did not...represent the intention of the testatrix...If judges were too ready to accept such contentions, it would risk undermining ...a fundamental principle of English law, namely that people should in general be free to leave their property as they choose, and it would run the danger of encouraging people to contest wills, which could result in many estates being diminished by...legal costs." 34
\end{abstract}

He was also conscious that "if the court sets aside a will, the result will be either that an earlier will prevails or that the rules of intestacy apply: either eventuality may result in an outcome that appears to comply with the wishes of the testatrix even less than that produced by the will at issue". ${ }^{35}$

Whatever impact the ageing process might have on the will-writing population, it is difficult to disagree with Lord Neuberger's general analysis on the policy justifications for Principle 2 in most cases. ${ }^{36}$ It is therefore ironic that, as will be seen later in this section, Lord Neuberger jeopardised the continued application of that principle in Gill itself.

The precise prerequisites for the principle arising, and its strength, have been the cause of uncertainty over the years, even before Lord Neuberger apparently cast doubt on the existence of the principle in Gill. Not all formulations mention the requirement that the testator read the will before executing it before the presumption is raised, ${ }^{37}$ but this ingredient is at the centre of other cases. $^{38}$

It was thankfully made clear by the House of Lords in the 1875 case of Fulton $v$ Andrew that Principle 2 is not a conclusive presumption even if it includes a reading requirement that has been satisfied. ${ }^{39}$ This is contrary to some earlier authorities holding that Principle 2 is conclusive (at least

\footnotetext{
${ }^{32}$ Ibid, at [26].

${ }^{33}$ Ibid, at [16].

${ }^{34}$ Ibid.

${ }^{35}$ Ibid, at [26].

${ }^{36}$ Cf. R. Kerridge, Parry and Kerridge: The Law of Succession, 13th edn. (London: Sweet \& Maxwell, 2016) at [5-49].

See also Reed, "Capacity and Want of Knowledge and Approval”, p.183.

${ }^{37}$ See, e.g., Hoff v Atherton [2004] EWCA Civ 1554 at [62] (Chadwick LJ).

${ }^{38}$ See. e.g., Gregson v Taylor [1917] P. 256, at 261 (Hill J).

39 (1875) 7 H.L. 448.
} 
in the absence of actual fraud). ${ }^{40}$ Judge Lewison QC has nevertheless interpreted Fulton as meaning that "it is only in an exceptional case that where a person of testamentary capacity reads his will, a court will refuse to infer knowledge and approval". ${ }^{41}$ He was prepared, however, to accept that, at least in cases of borderline capacity, "the more complex the will, the greater will be the need for the explanations" of the will's contents to the testator. ${ }^{42}$

Conversely, the courts have sometimes been willing to infer reading from due execution in order to raise the presumption. ${ }^{43}$ It seems that " $[\mathrm{t}]$ he appropriateness of the way in which a will is read to a testator and the reaction he had to it, however that may have been manifested, will depend on all the circumstances", and it will not necessarily be problematic if he reacts passively. ${ }^{44}$

Lord Neuberger's own formulation in Gill was that "[a]s a matter of common sense and authority, the fact that a will has been properly executed, after being prepared by a solicitor and read over to the testatrix, raises a very strong presumption that it represents the testatrix's intentions at the relevant time, namely the moment she executes the will". ${ }^{45}$ This could be read as imposing an additional requirement for legal advice to Principle 2, although it might limit the function of Principle 3 since "suspicious circumstances" may be removed by legal advice. It may be that there are several possible presumptions making up Principle 2, whose strengths vary according to the factors raising them. If true, this is not necessarily problematic, but it is something that would benefit from clarification.

In Gregson v Taylor, ${ }^{46}$ Hill J made some surprising remarks about the strength of Principle 2 as a presumption. He went as far as to say that "if it is said that [the documents] represent [a testator's] will and something more", i.e. something additional has been added to the will that he did not intend, then "before that something more can be rejected as not being his will it must be established beyond all doubt that it is not his will". ${ }^{47}$ If this is generally true, this would be higher than the burden imposed to prove knowledge and approval where Principle 3 is engaged (and seems

\footnotetext{
${ }^{40}$ See, e.g., Guardhouse v Blackburn (1866) 1 P. \& D. 109, impliedly criticised in Re Morris [1971] P. 62, at 76 (Latey J); Ross Martyn et al, Theobald on Wills, at [3-024].

${ }^{41}$ Brown v Deacy [2002] W.T.L.R. 781 at [11].

42 [2002] W.T.L.R. 781 at [16].

${ }^{43}$ See, e.g., Sherrington v Sherrington [2005] EWCA Civ 326 at [98] (Peter Gibson LJ).

${ }^{44}$ Re Endoya [2009] EWHC 2181 (Ch) at [99] (Deputy Judge William Trower QC).

${ }^{45}$ [2010] EWCA Civ 1430 at [14].

46 [1917] P. 256.

${ }^{47}$ Ibid, at 261.
} 
higher even than a standard of beyond reasonable doubt). This is another respect in which a member of the judiciary has caused confusion.

If Principle 2 is to continue, the law in this area would significantly benefit from a clarification of the precise requirements for the presumption to be raised and its implications. While reading might be reasonable (even if inferred), requiring legal advice would go too far in potentially robbing the presumption of a considerable amount of its practical benefit, although the absence of legal advice could be recognised as a good reason for rebutting the presumption (in combination with other factors). An onerous Principle 2 could also leave many cases where the solution is not governed by any presumption or its rebuttal, including because Principle 3 (depending on its nature and scope) does not apply either, which would again be practically undesirable.

\section{Knowledge and Approval's Relationship with Testamentary Capacity and Undue Influence}

This sub-section considers the relationship of want of knowledge and approval with testamentary capacity, one of Principle 2's clearer prerequisites, and testamentary undue influence. Such relationships are particularly important in light of the Law Commission's consultation paper.

In addition to Principle 2 itself (subject to its continuing validity), the propounder can also benefit from a presumption of due execution (where the requirements of the Wills Act appear to have been carried out), ${ }^{48}$ and of capacity in the case of a will that is rational on its face, ${ }^{49}$ and in that respect Principle 2 is consistent with other areas of succession law.

Despite the relevance of capacity to Principle 2, the courts have not always scrupled to distinguish inter alia testamentary capacity, want of knowledge and approval and undue influence. ${ }^{50}$ On Kerridge's analysis, pleadings themselves are often confused, perhaps deliberately due to the costs rules involved. ${ }^{51}$

There has nevertheless been some judicial disagreement as to whether or not testamentary capacity is a prerequisite for knowledge and approval. In Sharp v Adam, for example, the judge found that the alleged testator knew and approved of the disputed will, even though the testator's inability to speak, read or write meant that knowledge and approval could not be proved by

\footnotetext{
${ }^{48}$ See, e.g., Sloan, Borkowski's Law of Succession, pp.130ff.

${ }^{49}$ See, e.g., ibid, p.79. It has been seen that C.P. 231 has proposed a statutory presumption of capacity.

${ }^{50}$ See, e.g., Reed, "Capacity and Want of Knowledge and Approval”, pp.186-88.

${ }^{51}$ Kerridge, Parry and Kerridge, at [5-58]; see further Reed, "Capacity and Want of Knowledge and Approval”, p.186
} 
execution, ${ }^{52}$ and the judge also found that testamentary capacity was lacking. ${ }^{53}$ In Walters $v$ Smee, by contrast, Judge Purle QC recognised that "[g]iven [his] conclusions on lack of capacity, the question of want of knowledge and approval does not arise", and "[i]t is somewhat artificial to deal with it on the assumption that the deceased had capacity when [he had] held that she did not". 54

Some uncertainty arguably remained even when the Court of Appeal considered the matter in 2010. In Perrins v Holland, Sir Andrew Morritt C held that Barry makes clear that "the fact to be proved is knowledge and approval in the sense of acceptance of the contents", which "does not require full testamentary capacity". ${ }^{55}$ Despite these comments, Sir Andrew was prepared to accept that "[p]lainly testamentary capacity is a prerequisite to knowledge and approval because if the former is not shown there is no need to look for the latter". ${ }^{56}$ But he was not prepared to accept that knowledge and approval has to be proved where Parker $v$ Felgate ${ }^{57}$ (relating to changes in capacity or knowledge between instruction and signing) applies (the focus of the decision in Perrins), provided that "(a) the testator believes that it gives effect to his instructions and (b) it does in fact do so". ${ }^{58}$ As Moore-Bick LJ expressed it, "knowledge and approval requires no more than the ability to understand and approve choices that have already been made". 59 An appropriate conclusion following Perrins is that capacity is a pre-requisite for knowledge and approval, but that it is suitably adjusted to accommodate Parker v Felgate.

In a very welcome proposal, the Law Commission has provisionally proposed a clarification that testamentary capacity relates to the ability relevantly to know the contents of the will rather than whether the testator did so, ${ }^{60}$ which should help to clarify the relationship between the two. The very word "capacity" suggests an ability, while "knowledge and approval" relates more to a state of affairs.

Unlike execution, capacity and knowledge and approval, the absence of undue influence does not form part of the propounder's burden of proof. It is for the will's challenger to prove undue

\footnotetext{
${ }^{52}$ See, generally, R.F.D. Barlow et al, Williams on Wills, 10th edn. (London: Sweet \& Maxwell, 2014) at [3-022]; NonContentious Probate Rules 1987/2024., r. 13.

53 [2005] EWHC 1806 (Ch).

54 [2008] EWHC 2029 (Ch) at [129].

55 [2010] EWCA Civ 840; [2011] Ch. 270 at [28]; see also [63] (Moore-Bick LJ).

${ }^{56}$ Ibid, at [31]; see also [65] (Moore-Bick LJ).

57 (1883) 8 P.D. 171. See, generally, Sloan, Borkowski's Law of Succession, pp.78ff; 88ff.

58 [2010] EWCA Civ 840 at [32], approving [2009] EWHC 1945 (Ch) at [52] (Lewison J).

${ }^{59}$ [2010] EWCA Civ 840 at [64].

${ }^{60}$ C.P. 231 at [2.81]. Its preference, however, is simply to extend the Mental Capacity Act 2005 to testamentary capacity (Consultation Question 3).
} 
influence, and there is currently no relational presumption as there is with inter vivos transfers. ${ }^{61}$ In Gill v Woodall, Lord Neuberger thought it "rather unreal to consider arguments as to the nature and extent of the influence [the testatrix's husband] exerted on his wife to persuade her to leave the farm to the [Royal Society for the Prevention of Cruelty to Animals], when [he had] just concluded that she did not know that she was doing that very thing". ${ }^{62}$ This suggests that in order to be unduly influenced per se, the testator must have both testamentary capacity and knowledge and approval of the will. ${ }^{63}$

Kerridge has argued that a case where a beneficiary prepares a will whose contents the testator does not know and approve, there must have been either undue influence or fraud, and he has gone so far as to suggest that fraud or coercion should be presumed in such a case. ${ }^{64}$ But becoming involved in the preparation of the will of a potentially vulnerable person does not necessarily amount to fraud or coercion (the standard presently used in testamentary undue influence cases), and fraud is a particularly grave finding. The courts have favoured retaining the boundaries between knowledge and approval and other concepts even if they have not always policed those boundaries effectively, and it will be seen that want of knowledge and approval can extend beyond cases where the beneficiary was involved in preparation. Increased clarity on this matter would nevertheless be beneficial. It is noteworthy that "once fraud is established, all presumptions of due execution (and knowledge and approval) would cease to have any sway and the [propounder] would not be able to establish that the [will] was executed at a time when the Testatrix had testamentary capacity and knew and approved its contents". ${ }^{65}$ This is related to Principle 3, although it will be seen that there is doubt about whether Principle 3 can legitimately be used where true fraud is alleged. Since the Civil Procedure Rules came into force in 1999 the previous procedural restrictions ${ }^{66}$ on pleading facts relevant to any other ground of invalidity of a will without specifically pleading that ground itself no longer apply to probate claims, although any alleged ground of invalidity must be properly pleaded and particularised. ${ }^{67}$

\footnotetext{
${ }^{61}$ See, e.g., B. Sloan, "Reversing Testamentary Dispositions in Favour of Informal Carers" in Häcker and Mitchell (eds.), Current Issues in Succession Law. Cf. C.P. 231, ch. 7.

62 [2010] EWCA Civ 1430 at [66].

${ }^{63}$ See also, e.g., Poole v Everall [2016] EWHC 2126 (Ch); [2016] W.T.L.R. 1621 at [137] (HHJ David Cooke).

${ }^{64}$ R. Kerridge, "Undue influence and testamentary dispositions: a response" [2012] Conv 129.

${ }^{65}$ Re Gale [2010] EWHC 1575 (Ch) at [130].

${ }^{66}$ See, e.g., Kerridge, "Wills Made in Suspicious Circumstances”.

${ }^{67}$ See Rich, "What does 'want of knowledge and approval' mean in the 21 st century?", p.305 for discussion.
} 
While the Law Commission provisionally rejected the simple extension of the general equitable doctrine to the testamentary context, ${ }^{68}$ it proposed that a testamentary undue influence doctrine should be enshrined in statute, which would take either a "structured" or a "discretionary" form. ${ }^{69}$ A "structured" approach would involve a similar rebuttable presumption to the inter vivos version raised via a relationship of influence (itself presumed or proved) and a disposition calling for explanation. In the testamentary context, it would be decided whether a disposition calls for explanation based on either "the conduct of the beneficiary in relation to the making of the will" or "the circumstances in which the will was made". ${ }^{70}$ The Commission did not recommend any changes to the costs rules, ${ }^{71}$ hoping that, if its reforms to undue influence (and the extent of knowledge required for want of knowledge and approval) took effect, more cases would be litigated as undue influence claims and the question of presumptions would become less relevant to a narrower knowledge and approval doctrine. This may be true to some extent, but it will become clear that its suggestion is not a comprehensive solution.

The article must now address a matter that is perhaps even more crucial than the relationship of Principle 2 with other concepts (under the current law as distinct from a reformed law), namely whether Principle 2 has survived the difficult Court of Appeal decision in Gill v Woodall at all.

\section{The Trouble with Gill and its Aftermath}

The analysis of Lord Neuberger's remarks in Gill undertaken thus far suggests that he was a strong supporter of Principle 2 because of its important practical implications. Perhaps oddly then, and ironically raising a knowledge and approval issue of its own, when applying the unreported 1956 case of Re Crerar to cast doubt on Principle 3, ${ }^{72}$ Lord Neuberger appeared to approve Sachs J's further assertion there that " $[\mathrm{t}]$ he fact that the testatrix read the document, and...that she executed it, must be given the full weight apposite in the circumstances, but in law those facts are not

\footnotetext{
${ }^{68}$ C.P. 231, Consultation Question 36; see, e.g., B. Sloan, "Due rewards or undue influence? - Property transfers benefitting informal carers" [2011] Restitution Law Review 37.

69 C.P. 231, Consultation Questions 37-38.

${ }^{70}$ Ibid at [7.119]. The alternative "discretionary" approach might be a recipe for litigation, making the "structured" approach preferable.

${ }^{71}$ Ibid at [7.136].

${ }^{72}$ It was, however, the subject of an article published at 106 Law Journal 694 and the statements of law have been verified: see Re Morris [1971] P. 62, at 78.
} 
conclusive, nor do they raise a presumption" ${ }^{73}$ This may not be consistent with Lord Neuberger's other remarks in Gill about the importance of Principle 2, and significantly adds to the uncertainty of the law. The Law Commission has said that Lord Neuberger made his "very strong presumption" remarks "whist rejecting the idea that a formal evidentiary presumption of knowledge and approval will be raised", ${ }^{74}$ but that is surely unsatisfactory since either there is a presumption or there is not.

It is theoretically possible that Sachs $\mathbf{J}$ was saying that Principle 2 does not create an irrebuttable or legal presumption, but that would add little to saying that "in law those facts are not conclusive". Moreover, Durston treats evidential presumptions as a subspecies of legal presumptions, distinguishing them from "irrebuttable presumptions of law". ${ }^{75}$ It seems more likely that Sachs $\mathbf{J}$ was distinguishing conclusive rules of law, such as that rightly rejected in Fulton, from rebuttable evidential presumptions such as Principle 2, and asserting that neither a rule of law nor a rebuttable presumption existed in relation to knowledge and approval of a validly executed will by a testator with capacity (who had read it).

Further quotations from Re Crerar appear in Re Morris. ${ }^{76}$ On the basis that "inquiries touching the validity of a testamentary disposition have always been considered matters touching the conscience of the court", Sachs J rejected "the idea that there is any rule of law applicable to unusual cases which can so put that conscience into a strait-jacket as to preclude it from drawing inferences in the usual way and thus force the court to a decision which would, on the particular facts, be artificial". ${ }^{77}$ It is arguable that Sachs J's reference to "unusual cases" casts doubt on his own assertion that reading and duly executing the document raises no presumption, but his general approach seems inconsistent with Principle 2 and Lord Neuberger did not quote that aspect of the judgment. Is there therefore a distinction between a presumption that the will represents the testator's intentions at the relevant time (explicitly recognised by Lord Neuberger) and a presumption of want of knowledge and approval? This cannot possibly be a distinction that Lord Neuberger himself wished to draw, since his very formulation of the legal doctrine of want of knowledge and approval in the judgment is precisely that "the will 'represented one's testamentary intentions ". 78

\footnotetext{
${ }^{73}$ Gill $v$ Woodall [2010] EWCA Civ 1430 at [22].

${ }^{74}$ C.P. 231 at [7.15].

${ }^{75}$ G. Durston, Evidence: Text \& Materials, 2nd edn. (Oxford: OUP, 2011), ch. 4.

${ }^{76}$ [1971] P. 62, at 78, a mistaken drafting case (see, e.g., Ross Martyn et al, Theobald on Wills, at [3-025]ff).

${ }^{77}$ Quoted in Re Morris [1971] P. 62, at 78 and verified by Sachs LJ.

${ }^{78}$ Gill $v$ Woodall [2010] EWCA Civ 1430 at [14], quoting Fuller v Strum [2001] EWCA Civ 1879 at [59] (Chadwick LJ).
} 
The potential difficulties with Principle 2 that in my view are present post-Gill do not appear to have been particularly widely picked up by the judiciary, ${ }^{79}$ albeit that Sachs J's relevant words have been re-quoted. ${ }^{80}$ There are some cases where the court has potentially downplayed the significance of the presumption post-Gill. In Webster v Ashcroft, HHJ Purle QC invoked Principle 1 but admitted that satisfying that burden may be "assisted by established presumptions in an appropriate case". ${ }^{81} \mathrm{He}$ nevertheless proceeded to decide that the testatrix knew and approved of the disputed will's contents "irrespective of any presumption". ${ }^{82}$

In the post-Gill case of Wharton v Bancroft, however, Norris J did assert that "the Court can infer knowledge and approval from proof of capacity and proof of due execution" and that this plus reading over "raises a very strong presumption that it represents the testator's intentions at the relevant time". ${ }^{83}$ In Re Burns, the Court of Appeal's formulation was that "[i]t is right that in many a case proof of capacity and due execution will suffice to establish knowledge and approval". ${ }^{84}$

It may be argued that there are differences between an assertion that due execution by a testator with capacity will usually discharge a burden of proof and an assertion that there is a presumption (even a rebuttable one) to that effect. It is highly significant, however, that when giving judgment in the Supreme Court in Marley $v$ Rawlings (a case ultimately decided on rectification) Lord Neuberger said that:

\begin{abstract}
"There is a rebuttable presumption that the testator knew and approved the contents of a regularly executed will with unexceptional provisions. However, that presumption may be rebutted by evidence of the circumstances in which the will was prepared or executed [or] where the will is so worded as to cast doubt on whether the testator can have known or approved of its contents." 85
\end{abstract}

This is a softer view on whether Principle 2 exists, and what its prerequisites are, than the same judge expressed in Gill. ${ }^{86}$ Moreover, in Elliott v Simmonds, Gill was explicitly cited as authority for

\footnotetext{
${ }^{79}$ See also, e.g., Ross-Martyn et al, Theobald on Wills, at [3-017].

${ }^{80}$ See, e.g., Hawes v Burgess [2012] W.T.LR. 423 at [123] (HHJ Walden-Smith), upheld [2013] EWCA Civ 94.

${ }^{81}$ [2013] EWHC $1316(\mathrm{Ch})$ at [41].

82 [2013] EWHC $1316(\mathrm{Ch})$ at [42].

${ }^{83}$ [2011] EWHC $3250(\mathrm{Ch})$ at [28].

${ }^{84}$ Re Burns [2016] EWCA Civ 37 at [52] (McCombe LJ).

${ }^{85}$ [2014] UKSC 2 at [43].

${ }^{86}$ See also Elliott v Simmonds [2016] EWHC 732 (Ch) at [70] (Deputy Judge Edward Murray).
} 
the proposition that "the prima facie case is strengthened where the will has been prepared by and independent and experienced solicitor and read over to the testator", ${ }^{87}$ which seems to suggest that Lord Neuberger was acknowledging the existence of a weaker presumption strengthened by the addition of legal advice, rather than suggesting that it was a core feature of Principle $2 .{ }^{88}$

One case that very significantly did pick up the difficulty that I have highlighted is Inchbald v Inchbald, where Deputy Judge John Martin QC asserted:

“...the statement at the end of that quotation [from Sachs J] to the effect that execution after reading over does not raise a presumption is in conflict with an earlier passage in Lord Neuberger's own judgment which [he had] quoted above." 89

He opined that "[ $\mathrm{t}]$ hey may perhaps be reconciled by treating Sachs $\mathrm{J}$ as speaking of a legal presumption, and Lord Neuberger of an evidential presumption", 90 an argument considered above. He held that: "[w]hether that is so [or] not, however,...the correct approach is to treat execution after reading over as being merely one of a number of factors which may lead to the conclusion that the testator knew and approved of the contents of the will, although it will often be of great importance to that conclusion". ${ }^{91}$ He professed both to "have adopted the holistic approach to the evidence enjoined on me by Gill v Woodall", and to "have...borne in mind the policy argument referred to by Lord Neuberger" about the importance of being slow to declare wills invalid. ${ }^{92}$

While it is gratifying that the difficulty with Gill as regards Principle 2 has been identified by at least one member of the judiciary and is not merely a product of the author's imagination, the balance of authorities suggests that some version of Principle 2 still exists. This is not necessarily a problem, and indeed Deputy Judge Martin's approach is itself not free from difficulty. The law, nevertheless, is crying out for clarification on whether Principle 2 remains valid and, if so, what its scope is, particularly given the importance for practice that it does remain true.

It has been seen that the Law Commission's hope is that its proposed reforms to the undue influence doctrine will reduce the reliance on presumptions. It proposes that knowledge and approval should be specifically confined to a requirement that the testator:

\footnotetext{
${ }^{87}$ [2016] EWHC 732 (Ch) at [70] (Deputy Judge Edward Murray).

${ }^{88}$ See also Poole v Everall [2016] EWHC 2126 (Ch) at [116] (HHJ David Cooke).

${ }^{89}$ [2016] EWHC 3215 (Ch) at [8].

${ }^{90}$ Ibid.

${ }^{91}$ Ibid.

${ }^{92}$ Ibid.
} 
"(1) knows that he or she is making an will;

(2) knows the terms of the will; and

(3) intends those terms to be incorporated and given effect in the will." 93

While this would be a welcome clarification, specifying precisely what a testator needs to know/intend is not the same as specifying in which circumstances (if any) he will be presumed to know/intend it. Moreover, although it may be true as a matter of practice that most suspicious wills cases will be litigated as undue influence if the proposed reforms take effect, if knowledge and approval is to remain a separate requirement it would be helpful for practitioners to know if and in what circumstances it will be presumed so that they can advise clients effectively. Even if a presumption of undue influence clouds the distinction between it and knowledge and approval, it is noteworthy that it has been said that when the inter vivos undue influence doctrine is truly at issue "the influencee...will always know what he or she is doing; the question is why". 94

\section{Principle 3: "Suspicious Circumstances" Require Affirmative Proof of Knowledge and Approval}

In Perrins $v$ Holland, Sir Andrew Morritt $\mathrm{C}$ held that "it is clear from its origins that the requirement of knowledge and approval is a shorthand reference to the need for evidence to rebut suspicious circumstances". ${ }^{95}$ This statement is in itself potentially confusing, since suspicious circumstances might themselves rebut or otherwise affect Principle 2. It does, however, illustrate the historical importance attached to such circumstances.

In Barry v Butlin, alongside Principle 1, the other "well established" principle invoked by Parke B was that "if a party writes or prepares a Will, under which he takes a benefit, that is a circumstance that ought generally to excite the suspicion of the Court, and calls upon it to be vigilant and jealous in examining the evidence in support of the instrument, in favour of which it ought not to pronounce unless the suspicion is removed, and it is judicially satisfied that the paper propounded does express the true Will of the deceased". ${ }^{96}$ He declared the Privy Council to be

\footnotetext{
${ }^{93}$ C.P. 231 at [7.149].

${ }^{94}$ Leeder $v$ Stevens [2005] EWCA Civ 50, at [19] (Jacob LJ).

95 [2010] EWCA Civ 840 at [25].

96 (1838) 2 Moo. P.C. 480, at 482-483.
} 
"fully sensible of the wisdom of this rule, and the importance of its practical application on all occasions". 97

\section{The Scope of Suspicious Circumstances}

As might be expected, the precise scope of relevant "suspicious circumstances" has been the subject of considerable uncertainty over the decades, and Kerridge has criticised the concept for failing to make clear to what the suspicion relates. ${ }^{98}$ It might be sufficient simply to say that some facts raise a suspicion that the testator did not know and approve of the will's contents after all.

In Barry, with reference to Paske v Ollat ${ }^{99}$ inter alia, the rule was said to be that "there are cases of Wills prepared by a Legatee, so pregnant with suspicion, that they ought to be pronounced against in the absence of evidence in support of them...". ${ }^{100}$ It was nevertheless not true that "in every case in which the party preparing a Will derives a benefit under it, the onus probandi is shifted, and that not only a certain measure but a particular species of proof is thereupon required from the party propounding the Will". ${ }^{101}$ Parke B gave the example of a solicitor who receives $£ 50$ from an estate worth $£ 100,00$ having drafted a will for a "man of acknowledged competence and habits of business". ${ }^{102} \mathrm{He}$ considered it "obvious" that the burden would not be thrown back on the propounder in such circumstances, and continued:

"All that can be truly said is that if a person, whether attorney or not, prepares a Will with a Legacy to himself, it is, at most, a suspicious circumstance, of more or less weight, according to the facts of each particular case..."103

On the facts of Barry, suspicions were raised by the fact that the preparer had taken a quarter of the estate, ${ }^{104}$ albeit that the suspicions were removed because essentially the will was intended to be executed openly and fairly in the presence of "respectable" witnesses.

\footnotetext{
${ }^{97} \mathrm{Ibid}$, at 483; see further Re R [1951] P. 10, at 15, Leyne v McGhee $1982 \mathrm{WL} 967713$.

${ }^{98}$ Kerridge, "Undue influence and testamentary dispositions: a response", p.139.

${ }^{99}$ (1815) 2 Phillimore 323.

100 (1838) 2 Moo. P.C. 480, at 484.

${ }^{101}$ Ibid.

${ }^{102}$ Ibid, at 485.

${ }^{103}$ Ibid.
} 
The relationship between the preparer of the will and the testator may affect the application of the suspicious circumstances doctrine. That said, the mere fact that it is very common for spouses to leave property to each other, or for parents to benefit their children, will not prevent the application of the doctrine to preparers falling within those categories. In Franks $v$ Sinclair, the testatrix's son (a solicitor) conceded that the doctrine applied to him in circumstances where he had drawn up a will substantially benefiting him and excluding a nephew with whom he was not on speaking terms and to whom the testatrix was very close (in contrast to the previous will). ${ }^{105}$ In $R e$ Endoya, a beneficiary arranged for the taking of instructions and execution of the will, later suppressing that fact, but this was held not to be "remotely suspicious" because "she genuinely believed that she was taking steps to give effect to the deceased's wishes, in circumstances in which other members of the family had not taken the steps..., being steps which she genuinely and reasonably believed he wished to have pursued". ${ }^{106}$ It was held that "while a course of conduct in one set of circumstances may raise suspicions, a similar course of conduct in other circumstances may be entirely innocent and above suspicion". ${ }^{107}$ A highly fact-sensitive and potentially unpredictable approach is therefore in evidence.

Unsurprisingly, there has been some doubt on the extent to which suspicious circumstances will be present in cases beyond the beneficiary procuring or drafting the will (even if conversely not all cases where such a benefit is taken will necessarily excite suspicion). In Tyrell v Painton, it was confirmed that the suspicious circumstances doctrine was not confined to cases where the beneficiary had prepared the will, and on its facts extended the rule to circumstances where the will was prepared by the beneficiary's son. ${ }^{108}$ In Minns v Foster, Deputy Judge Michael Briggs QC opined that "there is no limit to the type of evidence which might persuade a court that it required something more than capacity plus due execution as evidence of knowledge and approval". 109 The beneficiary's care of the deceased and suggestibility arising from bereavement were considered

\footnotetext{
${ }^{104}$ Ibid, at 487-8. Kerridge, "Wills Made in Suspicious Circumstances", p. 323 has argued that Barry is truly a case of undue influence or fraud and did not involve a plea of want of knowledge and approval, but it has been widely treated as an authority on want of knowledge and approval.

${ }^{105}$ [2006] EWHC 3365 (Ch).

106 [2009] EWHC $2181(\mathrm{Ch})$ at [96] (Deputy Judge William Trower QC). See also, e.g., Blackman v Man [2007] EWHC $3162(\mathrm{Ch})$.

${ }^{107}$ [2009] EWHC 2181 (Ch) at [100] (Deputy Judge William Trower QC).

${ }^{108}$ [1894] P. 151.

${ }^{109} 2002$ WL 31914915 at [118].
} 
relevant (albeit obiter) in Re Key, ${ }^{110}$ and the suspicions were not dispelled. Such factors may have more relevance to undue influence (consistently with the Law Commission's approach), however, and it remains true that cases where a beneficiary was involved in the will's preparation are "classic examples" of suspicious circumstances. ${ }^{111}$ Moreover, in Ark v Kaur, and possibly in direct contrast to Minns, HHJ Cooke expressly rejected counsel's submission that "there is no limit to the range of circumstances which may excite suspicion". ${ }^{112}$ In $R e R$, it was emphasised that the suspicious circumstances must have some relevance to the preparation and execution of the will itself. Mere attachment to or affection for the beneficiary will go the other way in the sense of explaining the disposition. Relevance to preparation and execution was one limiting proposition from Williams, Mortimer and Sunnucks ${ }^{113}$ approved by HHJ Cooke in Ark. The other, despite Kerridge's arguments, was that the suspicious circumstances rule cannot be used "as a screen for allegations of fraud and dishonesty, which must be pleaded and proved". ${ }^{114}$

Gill v Woodall itself illustrates that suspicious circumstances can be present where the major figure aside from the testatrix neither draws up the will nor necessarily stands to benefit from it, and even where the beneficiary connected to that figure is not a human one. That said, Kerridge has suggested that Gill should have been analysed as a case of lack of capacity (not pleaded). ${ }^{115} \mathrm{Mr}$ and Mrs Gill had left their farm to the survivor in the first instance and then to the RSPCA, excluding their only daughter according to Mr Gill's wishes, despite Mrs Gill describing that Society as "a waste of time" and "a bunch of townies". 116

While at first instance in Gill Judge James Allen QC identified a wide range of suspicious circumstances, the Court of Appeal (in addition to their doubts about the validity of Principle 3 per $s e$ in the first place) held that many of them would on their own "fall well short of justifying the conclusion that Mrs Gill did not know or approve of the contents of the will". ${ }^{117}$ These included the attitude of Mrs Gill to the RSPCA during her lifetime; the non-provision for her daughter in spite of care provided in addition to labour on the farm (for which gratitude had been expressed). The Court of Appeal nevertheless held that:

\footnotetext{
${ }^{110}$ Re Key [2010] EWHC $408(\mathrm{Ch})$ at [119] (Briggs J).

${ }^{111}$ Hart v Dabbs [2001] W.T.L.R. 527 at [24] (Lloyd J).

112 [2010] EWHC 2314 (Ch) at [43] (HHJ Cooke).

${ }^{113}$ See now J. Ross Martyn et al, Williams, Mortimer \& Sunnucks - Executors, Administrators and Probate, $20^{\text {th }}$ edn. (London: Sweet \& Maxwell, 2013) at para. [13-23]ff.

114 [2010] EWHC 2314 (Ch) at [43].

115 Kerridge, Parry and Kerridge, at [5-47].

116 [2010] EWCA Civ 1430 at [29] (Lord Neuberger).

${ }^{117}$ Ibid, at [26] (Lord Neuberger).
} 
“...there is no doubt that the[se] sort of factors...may properly be added into the balance to support other factors, where they exist, which call into question whether the testatrix knew and approved of what was in her will.",118

The other, primary, factors were her agoraphobia, meaning that she feared leaving the farm and interactions with strangers, and that when she did so (particularly during meetings with her solicitor) the resulting anxiety was severe enough to limit her ability to concentrate and absorb information; that it was therefore "unlikely she would have been able to take in the entire words spoken and the effect thereof, in particular the provision for the [RSPCA] and the consequences thereof" at that meeting if the will had simply been read out (which the Court of Appeal ultimately considered probable); and that her words and conduct after signing the will were consistent with her anticipating that her family would inherit the farm. ${ }^{119}$

The fact that a will was prepared shortly before death may not itself excite suspicion even if a will had not previously been made, albeit that "there may be circumstances in which the known imminence of death may be a pointer towards the possibility that the deceased was in a state of mind in which he did not fully know and approve of what he was doing". ${ }^{120}$ In Ark, however, HHJ Cooke took a (perhaps overly) restrictive approach meaning that inter alia the testator's previous refusal to make a will was insufficiently connected to the process of drawing up and executing the disputed will to be relevant to Principle 3. It has been seen that Lord Neuberger in Gill accepted that, at least normally, "the mere fact that the terms of a will are surprising or worse should not, without more, raise a presumption that the testator did not know or approve of the will". ${ }^{121}$

If the "suspicious circumstances" doctrine survives Gill, it is undesirable for the court to take an overly formalistic approach to the circumstances that might excite suspicion, even if a considerable degree of evidence of whatever the circumstances are might be necessary in order to avoid undermining any Principle 2. It be seen in due course, however, that Principle 3 is itself doubtful following Gill.

\section{The Effect of Suspicious Circumstances}

\footnotetext{
${ }^{118}$ Ibid, at [27] (Lord Neuberger).

${ }^{119}$ Ibid, at [24] (Lord Neuberger), citing [2009] EWHC 3778 at [476].

${ }^{120}$ [2009] EWHC 2181 (Ch) at [102] (Deputy Judge William Trower QC).

${ }^{121}$ Gill v Woodall [2010] EWCA Civ 1430 at [46] (Lord Neuberger).
} 
In Re Morgan, Judge Mark Herbert QC opined that, once suspicious circumstances of some weight have been raised, "the relevant evidence then has to be evaluated in order to determine the issue as a question of fact". ${ }^{122} \mathrm{He}$ then added, perhaps confusingly, that "[a]t that stage...there is no presumption one way or the other". ${ }^{123}$

It is not always made clear whether suspicious circumstances potentially rebut Principle 2 (leading to a further opportunity for the propounder nevertheless to prove want of approval affirmatively, so that the presumption will not necessarily be fully rebutted by the presence of suspicious circumstances) or prevent Principle 2 from arising in the first place. In Gregson v Taylor, it was suggested that Principle 2 arose in the first place only "in cases where there is no fraud, or suspicion of fraud". ${ }^{124}$ It has been seen, however, that Marley may take a different approach, apparently suggesting that suspicious circumstances will rebut a presumption that has already arisen. ${ }^{125} \mathrm{He}$ did, however, define the scope of Principle 2 with reference to "unexceptional provisions".

Whether Principle 3 relates to the prerequisites for Principle 2 or provides a means of rebutting it of course depends on the formulations of Principle 2, and it was clear from the last section that not all such formulations include terminology relating to Principle 3. It is arguably denied the status of a true presumption if prevented from arising by matters extraneous to its definition. The practical importance of a widely applicable and strong Principle 2 has already been highlighted and, somewhat conversely, there is arguably little point in it being rebuttable if it arises in the first place only in the absence of suspicious circumstances. This is yet another matter requiring clarification, the best method perhaps being to say that Principle 3 potentially rebuts Principle 2 (provided both remain in existence). Facts related to Principle 3 would in addition be relevant where a Principle 2 presumption could not be raised on its own terms.

\section{Removing the Suspicion}

Barry introduces another uncertainty related to the means by which a "suspicion", once raised, may be removed: while Parke B held it unnecessary in all cases where the drafter takes a benefit under the will for "the precise species of evidence of the deceased's knowledge of the Will...to be in the shape of instructions for, or reading over the instrument, even", "[ $t$ ]hey form, no doubt, the most

\footnotetext{
122 [2008] W.T.L.R. 73 at [35].

${ }^{123}$ Ibid.

124 [1917] P. 256, at 261.

${ }^{125}$ [2014] UKSC 2 at [43] (Lord Neuberger). See also, e.g., Re Hinch [2013] EWHC 13 at [74] (Judge Behrens).
} 
satisfactory...description of proof, by which the cognizance of the contents of the Will, may be brought home to the deceased". ${ }^{126}$ As was seen in the last section, such reading might surely be pivotal in the establishment of Principle 2 rather than merely being evidence through which suspicion may be dispelled, ${ }^{127}$ albeit that there may be a distinction between merely "reading" and "reading over" by a solicitor. Of course, if Principle 2 does not arise where circumstances relevant to Principle 3 are present (an argument considered above), it makes sense for Principle 2's requirements to be found in the means through which the Principle 3 suspicions can be removed. If some version of both Principle 2 and Principle 3 survives, an important task for reformers of the law of want of knowledge and approval is to decide which factors form part of Principle 2 (presumed validity), which are factors that might dispel Principle 3 suspicions, and (if Principle 2 is not to arise where Principle 3 factors are present) which are relevant to both of these. It has been seen that a less onerous version of Principle 2 would serve the objective of upholding the general validity of wills.

Sometimes it is said that, where suspicious circumstances are present, it is for the propounder to convince the court of the "righteousness of the transaction". ${ }^{128}$ In Fuller v Strum, however, Peter Gibson LJ described this as "perhaps an unfortunate term" because it suggests that a moral judgment on the part of the court is required. ${ }^{129}$

In Wintle $v$ Nye, Viscount Simonds asserted that there were circumstances "so grave that [the degree of suspicion] can hardly be removed". ${ }^{130}$ On the facts of Wintle, in contrast to Barry, "the circumstances were such as to impose on the respondent as heavy a burden as can well be imagined" and could not be removed. ${ }^{131}$ The testatrix was an elderly lady "unversed in business", ${ }^{132}$ and the will left most of her estate to the solicitor who drafted it. She had expressed a wish to leave her residuary estate to charity only a few months before the disputed will was executed. She received no independent advice (the solicitor having made little effort to persuade her to acquire it), and he retained the will without giving her a copy.

Judge Behrens declared the case before him in Wyniczenko v Plucinska-Surowka may well have been a modern example of an instance where suspicion could "hardly be removed", since there

\footnotetext{
126 (1838) 2 Moo. P.C. 480, 485-6.

${ }^{127}$ See also, e.g., Franks v Sinclair [2006] EWHC 3365 (Ch).

${ }^{128}$ See, e.g., Fulton v Andrew (1875) 7 H.L. 448, at 472.

129 [2001] EWCA Civ 1879 at [33]. Cf. Kerridge, "Draftsmen and Suspicious Wills", p.160.

${ }^{130}$ [1959] 1 W.L.R. 284. For very detailed discussion, see Kerridge, "Wills Made in Suspicious Circumstances".

131 [1959] 1 W.L.R. 284, at 291.

132 Ibid.
} 
inter alia the will was prepared on the computer of the sole beneficiary, it was in English (a language that the Polish testatrix did not speak well) and made no provision for her family or her church, the beneficiary had not explained it to her, and he had behaved suspiciously after the testatrix's death (albeit that treating this fact as suspicious for these purposes is potentially inconsistent with $R e R) .{ }^{133}$ In $R e D$, moreover, suspicions were raised by the fact that previous wills had been professionally advised upon and drafted, whereas the disputed one was not; that it used spelling and language in a way that would have been anathema to the testatrix; that it contained inaccurate statements about her family that she would not characteristically have included; that it contained radical changes lacking explanation, the sole beneficiary being the barely known son of the testatrix's carer; and the medical evidence suggested that the testatrix was incapable of dictating the will. ${ }^{134}$ They were not removed.

That said, the burden of proof on the propounder remains the balance of probabilities rather than beyond reasonable doubt. ${ }^{135}$ In $\operatorname{Re}$ Good, ${ }^{136}$ counsel for the claimant accepted that she and her family were sufficiently involved in the execution of the will for suspicions to be excited, ${ }^{137}$ even though their approach to the drafting solicitor was probably made on the testatrix's initial instructions and he gave independent advice on the point. The burden was nevertheless held to be discharged because inter alia of an explanatory meeting with another solicitor earlier in the same month. ${ }^{138}$

Even where suspicions are aroused and the propounder has the burden of showing knowledge and approval affirmatively, Rimer $\mathrm{J}$ held in Re Reynolds that " $[\mathrm{t}]$ hat does not, however, mean that nothing less than positive evidence of such knowledge and approval will do", since "[i]f all the circumstances properly justify an inference that the testator did know and approve the contents of the disputed will, that will be sufficient to discharge the burden." 139 No such inference could be made on the facts, since the will was drawn up on the defendant beneficiary's instructions

${ }^{133}$ Wyniczenko v Plucinska-Surowka [2005] EWHC 2794 (Ch). See, similarly, Vaughan v Vaughan [2002] EWHC 699 (Ch).

${ }^{134}$ [2009] EWHC 1951 (Ch), seemingly also known as Dewas v Mackay. See further Kerridge, Parry and Kerridge, at para. [5-42].

${ }^{135}$ Fuller v Strum [2001] EWCA Civ 1879 at [72].

136 [2002] EWHC 640 (Ch).

${ }^{137}$ See also, e.g., Clancy v Clancy [2003] EWHC 1885 (Ch) at [62] (Rimer J), Allen v Emery [2005] EWHC 2389 (Ch).

${ }^{138}$ See also Minns v Foster 2002 WL 31914915.

${ }^{139}$ Re Reynolds [2005] EWHC $6(\mathrm{Ch})$ at [121]. 
and there was no safe evidence that it was in the testatrix's custody so that she must have read it. Sometimes, however, not very much evidence is required to rebut the suspicious circumstances. ${ }^{140}$

As with the issue whether Principle 3 rebuts Principle 2 or prevents it from arising in the first place, it is not always clear whether a decision is founded on the absence of suspicious circumstances in the first place or the fact that any suspicions have successfully been removed. ${ }^{141}$ In formulating its final proposals, the Law Commission should take care to ensure that a similar issue does not arise as between the raising and dispelling of its suggestion of a presumption of testamentary undue influence. In Minns v Foster, Deputy Judge Michael Briggs QC went so far as to say that there is an element of "artificiality in considering, having heard all the evidence on knowledge and approval, whether the circumstances would have given rise to a sufficient suspicion" to necessitate an enquiry. ${ }^{142}$ The claimant had "risen to the challenge of proving knowledge and approval by evidence other than mere capacity and due execution, so that the question whether there was a burden on her to do so is of essentially historic interest only."143

This somewhat presages the approach taken several years later in Gill, as will be seen in the next sub-section. In Gill itself, the possibilities (which the Court of Appeal rejected in any case) that Mrs Gill attended a previous meeting with her solicitor or that she read the draft will in advance of the execution meeting, and the fact that the will was read to her at the execution meeting were not enough to allay the suspicion on the traditional approach in this "exceptional" case.

\section{Gill's One-Stage Approach and its Aftermath}

In Gill v Woodall, Lord Neuberger described the value of the "two-stage" approach, of establishing whether there were suspicious circumstances and then whether the propounders had allayed those suspicions, as "questionable". ${ }^{144}$ He considered preferable the approach outlined by Sachs $\mathrm{J}$ in $R e$ Crerar (the same unreported case creating the difficulties with Principle 2 considered in the last section), namely that the court should "consider all the relevant evidence available and then, drawing such inferences as it can from the totality of that material,...come to a conclusion whether or not those propounding the will have discharged the burden of establishing that the testatrix knew

\footnotetext{
${ }^{140}$ See, e.g., Boudh v Bodh [2007] EWCA Civ 1019; Shuck v Loveridge [2005] EWHC 72 (Ch).

${ }^{141}$ See, e.g., In the Estate of Wilkes [2006] W.T.L.R. 1097.

1422002 WL 31914915 at [121].

${ }^{143}$ Ibid.

144 [2010] EWCA Civ 1430 at [22].
} 
and approved the contents of the document". ${ }^{145}$ This approach may have merit given the possibility of debate over which circumstances are "suspicious" in the first place, whether a factor forms part of Principle 2 or is a means by which a suspicion may be removed, and on particular facts whether a suspicion has been removed or simply never raised in the first place. His suggestion, however, causes its own difficulties.

Lord Neuberger was anxious that Gill should not be seen as "something of a green light to disappointed beneficiaries...to challenge the will even where it has been read over to the testatrix, or to appeal a full and careful first instance decision upholding a will's validity". ${ }^{146} \mathrm{He}$ emphasised the "exceptional" nature of the case, since the testatrix suffered from an extreme version of a rare condition, and the judge was being reversed on the facts because the findings through which he held Principle 3 to be rebutted were not open to him on the evidence. Reed nevertheless opines that the Gill approach means that "attacking wills on the basis of want of knowledge and approval may have a greater chance of success", ${ }^{147}$ and this will be particularly true if it casts doubt on Principle 2 as well.

Despite all of this, Lord Neuberger found it "none the less convenient to follow the twostage process adopted by the judge below in Gill, since "the answer should be the same" as if a single question had been posed. ${ }^{148}$ This in itself contributes to the uncertainty in, and unsatisfactory nature of, the law. The answer may well be the same in many cases where a judge considers the evidence in a lengthy trial, but surely some of the core advantages of presumptions and precision on the circumstances in which they are both raised and rebutted is that they shape legal advice and might avoid a trial altogether. ${ }^{149}$ These advantages are undesirably lost if Principles 2 and 3 are weakened.

Responses to Gill on whether Principle 3 exists and what its scope is have been mixed. Lord Neuberger's suggested one-stage approach has not universally been taken up. In Cushway v Harris, for example, Henderson J proceeded to adopt the traditional two-stage approach without reference to Gill, although it is true that the defendant beneficiary did not appear before him and the

\footnotetext{
145 Ibid.

${ }^{146}$ Ibid, at [66].

${ }^{147}$ Reed, "Capacity and Want of Knowledge and Approval”, p.188.

148 [2010] EWCA Civ 1430 at [23].

149 See, in a different context, M. George and B. Sloan, "Presuming Too Little About Resulting and Constructive Trusts?" [2017] Conv 305.
} 
circumstances of the case were extremely questionable. ${ }^{150}$ The same approach, however, was taken in Pearce $v$ Beverley following a full trial. ${ }^{151}$

Giving a Court of Appeal judgment in Fitzgerald v Henry, moreover, Rafferty LJ asserted both that the appeal "raises no issue of law, precedent or other matter of general significance" 152 but also that "[s]uspicious circumstances where made out place the onus on the propounder of the will to prove knowledge and approval", whereas "[a]bsent suspicious circumstances, the Court will assume the deceased knew and approved the will if it were read to him" (without apparently citing direct authority for those propositions). ${ }^{153}$ Hardly a ringing endorsement of Lord Neuberger's approach in Gill.

In Wharton $v$ Bancroft, Norris $\mathrm{J}$ potentially clouded the issue of a one-stage versus twostage approach by saying that he would decide the case "on the totality of the evidence without tracing the shifting evidential burden". ${ }^{154}$ The very suggestion that the evidential burden shifts, however, may hark back to a two-stage approach, while the emphasis on "totality", seen in other cases, ${ }^{155}$ may be an attempt to apply a one-stage approach. Reed does indeed regard Wharton as a case where the one-stage approach was applied, ${ }^{156}$ although other cases have been clearer. It has been seen that in Webster $v$ Ashcroft HHJ Purle decided the case "irrespective of any presumption". ${ }^{157}$ In Lloyd $v$ Jones, moreover, it was emphasised that knowledge and approval was to be "assessed on the basis of the evidence as a whole". ${ }^{158}$

In Re Butcher, in a clear attempt to marry the two approaches, it was held that "Lord Neuberger in Gill did not rule out use of the two stage approach for the future", but that it was "clear from the judgment at [22] that he favoured instead a single stage approach". ${ }^{160}$ Deputy Judge Lesley Anderson QC held that the correct approach was to apply the one-stage test in the first instance, following which the "two stage test can usefully be deployed as a cross-check to the conclusions reached using the single stage test". ${ }^{161}$ In the case at hand, she concluded that the

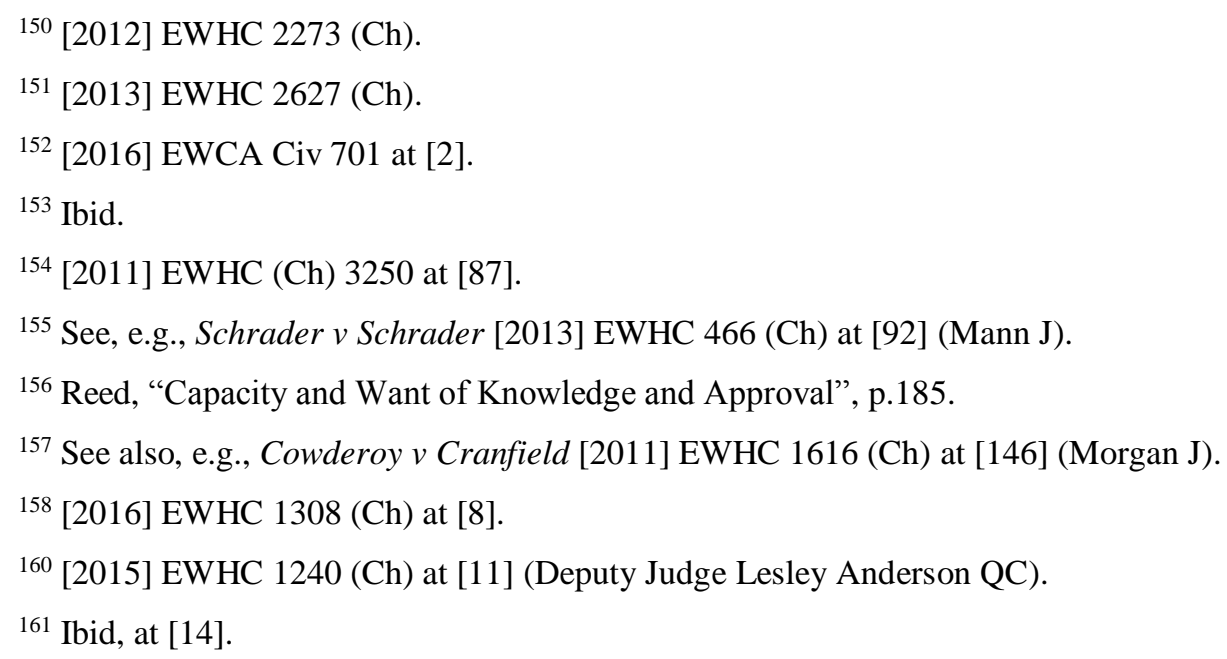


propounder had satisfied the burden "by considering all of the evidence in the holistic way approved...in Simon v Byford and, in those circumstances, it is not necessary or helpful for [her] to decide this case by reference to a strict application of the legal and evidential burdens of proof". ${ }^{162}$ She then held that the challenger would have established suspicious circumstances "but that any degree of suspicion was relatively low because it was not a case where the [later, disputed] Will was procured by the person benefitting under it", and "[o]n a full consideration of all the evidence, [she] would have found that [the propounder of the later will] had amply rebutted any such prima facie case". ${ }^{163}$

In Simon v Byford, the Court of Appeal had held that " $[\mathrm{t}] \mathrm{he}$ correct approach for the trial judge is clearly set out in Gill v Woodall...[i]t is a holistic exercise based on the evaluation of all the evidence both factual and expert". ${ }^{164}$ But in the immediately preceding passage Lewison LJ might have detracted from that very clarity by saying that " $t]$ he reason for the [want of knowledge and approval] requirement is the need for evidence to rebut suspicious circumstances". 165

In Re Burns in 2016, the Court of Appeal apparently confirmed it to be unnecessary for the judge to follow the two-stage approach. ${ }^{166}$ It was nevertheless also confirmed in Re Burns that affirmative evidence would be required where there were suspicious circumstances, albeit that sometimes not very much evidence is required.

It seems, therefore, that the courts have struggled to dispense with the notion of "suspicious circumstances" despite Gill, another source of confusion and uncertainty in the law. It has been seen that the Law Commission hopes to move "suspicious circumstances" cases to be covered by a new law of undue influence. That may be appropriate, since in many cases the reason why the testator has not acquired the requisite knowledge might be a relationship of influence that could justifiably be presumed undue, even if it falls short of the current "coercion" threshold. Undue influence may be a more apt description of the reason that the will is invalid, such that the lowering of the threshold is acceptable, and it is relatively clear that a case such as Wintle or Wyniczenko could be accommodated within the Law Commission's approach.

There are, however, at least two potential difficulties. First, the Commission's suggestion is partly premised on the assertion that "presumptions appear to have less relevance in the current state of the law given the holistic, one-stage approach to knowledge and approval preferred by the

\footnotetext{
162 Ibid, at [51].

${ }^{163}$ Ibid, at [53].

164 [2014] EWCA Civ 280 at [47] (Lewison LJ).

${ }^{165}$ Ibid.

${ }^{166}$ Re Burns [2016] EWCA Civ 37 at [56] (McCombe LJ).
} 
Court of Appeal in Gill v Woodall", ${ }^{167}$ whereas the above analysis implies that this is an optimistic view. Secondly, the Commission has admitted that in other cases, "the key issue, other than the testator's capacity, would continue to be whether the testator knew and approved of the terms of the will". ${ }^{168}$ Arguably problematically, the Commission gave Gill $v$ Woodall as an example of such a case not involving suspicious circumstances, ${ }^{169}$ whereas Lord Neuberger omitted expressly to say that it was not such a case even if he preferred a different methodology. That case also demonstrates that the influencing behaviour may not always come from an ultimate beneficiary. The law of want of knowledge and approval might therefore need some reform beyond clarifying the requirements scope, even if it is a statement that want of knowledge and approval should not be pleaded in some circumstances.

\section{Synthesis and Conclusion}

This article has taken three core principles on the law of want of knowledge and approval (that a will's propounder must "prove" it; that a testator with capacity who duly executes a will is presumed to know and approve of its contents; and that suspicious circumstances require affirmative proof of knowledge and approval) and highlighted several areas of uncertainty and confusion surrounding them. These include: the extent of "knowledge" required; the relationship of want of knowledge and approval with other succession law doctrines; the precise requirements for Principle 2 and the strength of the presumption; and the scope and effect of "suspicious circumstances" for the purposes of Principle 3 (and how these latter two matters interact with each other).

The main focus, however, has been on the continued existence and validity of Principles 2 and 3. On Banerjee's analysis, "Lord Neuberger's one stage approach [in Gill] seems to eject [the] presumption [represented by Principle 2 in this article] and shift the burden of proof to the propounder, who will have to prove knowledge and approval in addition to testamentary capacity". ${ }^{170}$ It could certainly be argued that there is a logical consistency to saying that neither Principles 2 nor 3 now exist. If (per Sachs J) the facts involved in Principle 2 do not give rise to a presumption, there is nothing for the will challenger to rebut using Principle 3 (and the propounder does not have to rebut Principle 3 either). The facts involved in Principles 2 and 3 would simply

\footnotetext{
${ }^{167}$ C.P. 231 at [7.147].

${ }^{168}$ Ibid, at [7.146].

${ }^{169}$ Ibid.

${ }^{170}$ R. Banerjee, “Gill v RSPCA: Law, Principle and Policy” (2011) 3 King’s Student L.R. 92, at 94.
} 
become part of the overall burden that the propounder has (by virtue of Principle 1, and would have had in any event if he could not raise Principle 2), unmitigated under this analysis of the current, post-Gill law, albeit that in most cases the Principle 2 facts will mean that the court declares for the propounder. The serious difficulty with this interpretation, however, is that in other parts of Gill Lord Neuberger seemed very clear that Principle 2 does exist and that it is of very considerable practical importance. If Principle 2 does indeed exist, what of the possible abolition of Principle 3 through Lord Neuberger's one-stage approach? If that abolition means that the challenger need not point to "suspicious circumstances" to rebut Principle 2, is it for the court alone to determine whether Principle 2 is sufficient to discharge the burden imposed by Principle 1? This renders Principle 2 pretty meaningless as a "presumption". Perhaps it means that the narrow approach to "suspicious circumstances" should no longer be applied, although Lord Neuberger was still fairly rigorous as to which circumstances were primarily relevant and which were merely supportive in the context on the facts of Gill. Or perhaps it means that the challenger does have to point to "suspicious circumstances", but rather than shifting the burden back to the propounder once proved the court simply has to evaluate their relevance on their own terms. This approach is reflected in some of the pre-Gill cases anyway.

It seems unlikely that Principle 1 will be removed from the scope of want of knowledge and approval. While the absence of undue influence is on the other side of the "line" in respect of the propounder's burden, it is arguable that knowledge and approval is closer to testamentary capacity than the absence of undue influence and therefore should in principle form part of that burden. If knowledge and approval is to continue as a separate requirement and were to be reformed in its own right, the preferable approach might therefore be to confirm Principle 2 as a true presumption (albeit a rebuttable evidential one) in view of the serious practical difficulties that might otherwise ensue, provided that its precise requirements can also be clarified.

As regards the facts that might somehow undermine the presumption (traditionally represented by Principle 3 but now undermined by Lord Neuberger and thought better dealt with through undue influence by the Law Commission), the law would also be improved if it could be confirmed whether they truly are potentially rebutting a presumption that has already arisen (with the advantages described above) rather than preventing it from arising in the first place. It should also be confirmed that a potentially wide range of circumstances might accomplish whatever process is occurring, albeit that (for example) the mere fact that a will is surprising will not necessarily be enough. It might be beneficial to dispense with the adjective "suspicious", which may undesirably imply wrongdoing that has not necessarily occurred. The simple terminology of "potentially rebutting" circumstances (if that is indeed what they do) may be better. As for whether 
the burden of proof should revert back to the propounder, it might seem unnecessarily complex for it to do so, since it may already have shifted once since it was originally with the propounder by virtue of Principle 1 because of its potential move to the challenger under Principle 2, and the propounder may have no further evidence on which he can rely depending on the content of Principle 2. That said, it may be easier to conceptualise what is happening if it does so shift, rather than having the court simply evaluate simultaneously whether there are "suspicious"/"potentially rebutting" circumstances and whether these have been removed or rendered inoperative.

While the Law Commission accepted that "reform could proceed by way of clarifying the presumptions that apply in the area of knowledge and approval" as outlined in this article, ${ }^{171}$ it preferred to address several of the difficulties in the area by reforming testamentary undue influence. This may well be an effective method of dealing with many of the difficulties identified with Principle 3. It has been seen, however, that this may not be a comprehensive solution in light inter alia of the value of Principle 2.

Whatever particular course is taken, clarification is important and necessary in the light of the potentially increasing scope for will challenges and conversely the traditional emphasis placed on testamentary freedom in England and Wales. ${ }^{172}$ This will be an important task for the Law Commission and then Parliament, or perhaps ultimately the judiciary themselves.

\footnotetext{
${ }^{171}$ C.P. 231 at [7.148].

${ }^{172}$ See, recently, Ilott $v$ The Blue Cross [2017] UKSC 17.
} 